\section{Satisfaction with food-related life and life satisfaction: a triadic analysis in dual-earner families}

\author{
Satisfacción con la alimentación y la vida: \\ un análisis triádico en familias con dos \\ fuentes de ingresos
}

\section{Satisfação com a vida relacionada à alimentação e satisfação com a vida: uma análise triádica em famílias com duas fontes de renda}

Berta Schnettler 1,2

Edgardo Miranda-Zapata 1

Klaus G. Grunert 3

Germán Lobos 2,4

María Lapo 2

Clementina Hueche 1

doi: 10.1590/0102-311X00090619

\begin{abstract}
This study explored the spillover and crossover associations between satisfaction with food-related life and life satisfaction in mothers, fathers and adolescent children in dual-earned families. This is a cross-sectional design study with mothers, fathers and children surveyed in Temuco, Chile. The participants were 303 dual-earner parents and their adolescent children (mean age 13.3 years, 51.5\% female). Actor-partner Interdependence Model (APIM) and structural equation modeling were used to explore spillover (actor effect) and crossover (partner effect) associations among family members. As a result, fathers' satisfaction with food-related life was positively associated with their own life satisfaction ( $p \leq 0.01$ ), as well as with their partner's (mother's) satisfaction with life $(p \leq 0.05)$, but not with their adolescent child's life satisfaction $(p>0.1)$. Mothers and children presented positive spillovers between their own levels of satisfaction with food-related life and life satisfaction $(p \leq 0.01)$. No crossover effects were found between mothers and children $(p>0.1)$. This study results underscore the positive association between satisfaction with food-related life and life satisfaction among members of dual-earner families with adolescent children. Special efforts should be made by dual-earner parents to improve the variables related to their satisfaction with food-related life as well as their children's satisfaction.
\end{abstract}

Personal Satisfaction; Adolescent; Feeding

\section{Correspondence}

B. Schnettler

Universidad de La Frontera.

Av. Francisco Salazar 01145, Casilla 54-D, Temuco, Chile.

berta.schnettler@ufrontera.cl

1 Universidad de La Frontera, Temuco, Chile.

2 Universidad Católica de Santiago de Guayaquil, Guayaquil,

Ecuador.

3 Aarhus University, Aarhus, Denmark.

4 Universidad de Talca, Talca, Chile. 


\section{Introduction}

Subjective well-being designates the psychosocial aspects of quality of life and consists of positive and negative effects and cognitive assessment of satisfaction with life 1 . Satisfaction with life includes assessing what individuals do with their lives as a whole and in different life domains such as work, family or food. Studies related to this issue seek to promote well-being and life satisfaction by identifying the variables related to them 2 . Subjective well-being, life satisfaction and food-related life satisfaction have been associated with positive behaviors, such as healthful eating habits 3,4,5,6,7,8,9,10,11, greater family support, more frequent family meals and higher family cohesion around eating 5,9,10,11,12,13,14. However, competing demands for time and energy of working parents may contribute to fewer meals prepared or eaten at home as well as poorer nutritional quality of meals 15,16,17,18, which may affect their own and their children's satisfaction with food-related life and life satisfaction.

Food is one of the domains related to life satisfaction, and satisfaction with food-related life has been shown to be positively associated with life satisfaction 19,20. Recent studies involving adolescents $13,14,21,22,23,24$, young adults 5,6, adults 14,25 and older adults ${ }^{4}$ provide evidence supporting this relationship among individuals. However, individuals involved in reciprocal relationships influence each other's thoughts, emotions 26,27 and also eating habits, as has been reported among members of the same family 6,28. The Spillover-Crossover Model (SCM) proposes that positive or negative experiences in a life domain can be transmitted to other domains within an individual, but also to those closer to them. Whereas spillover is an intra-individual transmission of stressors (negative spillover) or positive experiences (positive spillover), crossover is a dyadic, inter-individual transmission of stressors (negative crossover) or positive experiences (positive crossover) 29. The bidirectional crossover influence is especially important among family members 30, where the interdependence between individuals, structures and processes is recognized, according to the family system theory 31 . While most studies based on the SCM have focused on the crossover of negative experiences 32 , few studies have assessed crossover of positive experiences, such as life satisfaction 33, happiness 34 and family support 27 . Furthermore, while crossover has been extensively studied in couples, few studies have assessed the crossover between parents and their children 30 . Moreover, most studies have assessed crossover using dyads, whereas the available literature shows only one study analyzing the crossover from a triadic point of view 27 . To the best of our knowledge, there are no studies examining the relationships between satisfaction with food-related life and satisfaction with life using a triadic approach on the interdependencies between both parents and their children in dual-earner families. Therefore, this study aims to explore the spillover and crossover associations between satisfaction with food-related life and life satisfaction in mothers, fathers and adolescent children in dual-earner families. We hypothesized that family members who reported higher satisfaction with food-related life would likely present higher life satisfaction (positive spillovers), while the individual's satisfaction with food-related life would be also associated with the other family members' higher life satisfaction (positive crossovers).

\section{Methods}

\section{Sample and procedure}

Non-probability sampling was used to recruit a sample of 303 dual-earner couples with at least one adolescent child between 10 and 17 years old in Temuco, Chile. Married and unmarried cohabiting couples were included as a growing preference for cohabitation instead of legal marriage has recently been observed in Chile 35. Participants were recruited from seven schools that attend socioeconomically diverse populations. Directors from each school signed authorization letters to conduct the research with their students and provided a list of students from fifth grade and up (corresponding to a minimum age of 10) with their parents' telephone numbers. Parents were contacted by trained interviewers who explained the study objectives and the strictly confidential treatment of the information obtained. Then, the interviewers provided detailed information about the questionnaires, 
asking if both parents and one of their children between 10 and 17 years wanted to participate in the study. Interviews were conducted in participants' households. After all parents signed a written informed consent and adolescents signed an informed assent form, the questionnaires were applied to both parents and one child over 10 years old by a trained interviewer. Interviewee's anonymity was ensured. The study was conducted between May and August 2017 and the study design was approved by the Research Ethics Committee of the Universidad de La Frontera (Protocol number 005/2016). A pilot test of the questionnaires was conducted with 20 families following the same recruitment method. As the instrument pilot test was satisfactory, no changes were required in the questionnaires or interview procedure.

\section{Measures}

The following instruments were answered by mothers, fathers and adolescents:

(a) Satisfaction with Life Scale (SWLS): SWLS 36 is a scale composed of five items grouped into a single dimension used to evaluate overall cognitive judgments about a person's own life ("In most ways my life is close to my ideal"; "The conditions of my life are excellent"; "I am satisfied with my life"; "So far I have gotten the important things I want in life"; "If I could live my life over, I would change almost nothing"). The Spanish version of the SWLS was used ${ }^{77}$, which has shown good internal consistency in previous studies with adolescents aged between 10 and 17 years (Cronbach's alpha $=0.90-0.91$ ) and adults (Cronbach's alpha $=0.89-0.90$ ) in Chile 6,7,8,14,21. Interviewees were asked to indicate their degree of agreement with each statement using a 6-point Likert scale (1: completely disagree; 6: completely agree). In this study the SWLS presented good internal reliability (Ordinal alpha mothers $=0.919$, fathers $=0.929$, adolescents $=0.902$ ). SWLS scores are the sum of the five items of the scale with a potential 5-30 range. Higher scores indicate higher satisfaction with life.

(b) Satisfaction with Food-related Life (SWFL): SWFL 38 is a scale composed of five items grouped into a single dimension used to evaluate a person's overall assessment of their food and eating habits ("Food and meals are positive elements"; "I am generally pleased with my food"; "My life in relation to food and meals is close to ideal"; "With regard to food, the conditions of my life are excellent"; "Food and meals give me satisfaction in daily life"). The Spanish version of the SWFL was used 37, which has shown good internal consistency in studies with adolescents aged between 10 and 17 years (Cronbach's alpha $=0.89-0.91$ ) and adults (Cronbach's alpha $=0.76-0.86)$ in Chile 6,7,8,14,21. Interviewees were asked to indicate their degree of agreement with each statement using a 6-point Likert scale (1: completely disagree; 6: completely agree). In this study the SWFL showed good internal reliability (Ordinal alpha mothers $=0.908$, fathers $=0.901$, adolescents $=0.913$ ). SWFL scores are the sum of the five items of the scale with a potential 5-30 range. Higher scores indicate higher satisfaction with food-related life.

The Spanish versions of the SWLS and SWFL were obtained following the procedure proposed by Hambleton 39 . The first step was an individual translation performed by two expert professionals in English, one professional unfamiliar to the evaluated scale and the other who had experience in such evaluations. In the following step the research team discussed both translations, reaching an agreement. Each of the items on the scale was evaluated to guarantee their semantic, cultural and conceptual equivalence. The third step was the back-translation of the scale by a native English professional with mastery in Chilean Spanish. Finally, the scale was reviewed by the research team.

The discriminant validity of the SWLS and SWFL was previously demonstrated in samples of undergraduate students, adolescents and adults in Chile 5,6,12,14,25.

The three family members were asked about their age. Women were asked about the number of family members and the number of children. Education level and occupation of the householder were used to determine socioeconomic status 40 .

\section{Data analysis}

Descriptive analyses were conducted using SPSS v. 23 (https://www.ibm.com/). The Actor-partner Interdependence Model (APIM) was assessed using structural equation modeling (SEM) to explore the spillover and crossover associations between satisfaction with food-related life and life satisfaction among dual-earner parents and one adolescent children ${ }^{26}$. Usually, the APIM uses the dyadic 
interaction as the unit of analysis 25 . However, following Katapodi et al. 27, a novel approach for triadic analysis based on methods for distinguishable dyads was used. Therefore, each family member's satisfaction with food-related life (independent variables) was viewed as potentially associated with satisfaction with life experienced by the three family members (dependent variables). In the APIM framework, each family member is considered to be an actor as well as a partner in the analysis 28 . The association between the satisfaction with food-related life of one member of the triad with their own life satisfaction is referred to as "actor effects" (spillover). The associations between satisfaction with food-related life of one member of the triad with the life satisfaction of the other members of the triad is referred to as "partner effects" (crossover). The APIM controls for the extent to which each family member's satisfaction with food-related life is affected by the others family members' satisfaction with food-related life by a correlation between independent variables of each member of the triad. The APIM also includes correlations between the residuals errors of the dependent variables of each member of the triad (each family member's life satisfaction), which controls for other sources of interdependence between them 26 .

SEM was conducted using MPlus 7.11 (https://www.statmodel.com/). Parameters of the structural models were estimated using the robust unweighted least squares (ULSMV). Considering the ordinal scale of the items, the polychoric correlation matrix was used to perform the SEM analysis. The Tucker-Lewis index (TLI) and the comparative fit index (CFI) were used to determine the model fit of data. The TLI and CFI indicated a good fit with a value above 0.95 , while 0.90 was considered a cut-off point for establishing an acceptable fit. Furthermore, the root mean square error of approximation (RMSEA) was considered. The RMSEA is a poorness-of-fit measurement. A good fit is found when the value of the RMSEA is lower than 0.06, whereas an acceptable fit corresponds to a value lower than $0.0841,42$.

\section{Results}

\section{Sample description}

A total of 303 dual-earner parents with one adolescent child participated in the study. Table 1 presents sociodemographic characteristics of the sample and each family member's SWLS and SWFL average scores.

\section{APIM results}

The model that assessed the APIM association between the three family members' satisfaction with food-related life and their levels of satisfaction with life had fit indices showing a good fit with the data $(\mathrm{CFI}=0.994$, TLI $=0.994$, RMSEA $=0.013)$. Significant correlations (covariance) were found between the satisfaction with food-related life of both parents $(r=0.564, p=0.000)$ as well as between the residual errors of both parents' life satisfaction $(r=0.315, p=0.000)$. Non-significant correlations were found between satisfaction with food-related life of mothers and children $(\mathrm{r}=-0.036$, $\mathrm{p}=0.586)$ as well as between the residual errors of both family members' life satisfaction $(\mathrm{r}=0.096$, $\mathrm{p}=0.188$ ). Similarly, non-significant correlations were found between satisfaction with food-related life of fathers and children $(\mathrm{r}=0.021, \mathrm{p}=0.730)$ as well as between the residual errors of both family members' life satisfaction ( $\mathrm{r}=-0.052, \mathrm{p}=0.515)$.

Inspection of every item loading indicated no issues with the measurement model. The results from the structural model estimation are shown in Table 2. The path coefficients indicate that the fathers' satisfaction with food-related life was positively associated with their own life satisfaction ( $\mathrm{p} \leq$ 0.01). They also indicate that this satisfaction was positively associated with their partner's (mother's) satisfaction with life ( $\mathrm{p} \leq 0.05)$, but not with their adolescent child's life satisfaction $(\mathrm{p}>0.1)$. Still, the path coefficients indicate that mothers' satisfaction with food-related life was positively associated with their own life satisfaction ( $\mathrm{p} \leq 0.01$ ), but not with their partner's (the father's) and children's life satisfaction ( $p>0.1$ ). Likewise, adolescent children's satisfaction with food-related life was positively associated with their own life satisfaction $(\mathrm{p} \leq 0.01)$, but not with their mothers and fathers' $(\mathrm{p}>0.1)$ 
Table 1

Sample characteristics $(n=303)$. Temuco, Chile, 2017.

\begin{tabular}{lc}
\hline Characteristic & Total sample \\
\hline Mother's age [mean (SD)] & $40.9(7.4)$ \\
Father's age [mean (SD)] & $43.2(7.2)$ \\
Number of family members [mean (SD)] & $4.3(1.1)$ \\
Number of children [mean (SD)] & $2.4(1.0)$ \\
Interviewed children age [mean (SD)] & $13.3(2.4)$ \\
Interviewed children gender (\%) & \\
Female & 51.5 \\
Male & 48.5 \\
Socioeconomic status (\%)* & \\
High and upper-middle & 11.2 \\
Middle-middle & 20.8 \\
Lower-middle & 37.0 \\
Low & 21.5 \\
Very low & 9.6 \\
Satisfaction with life [mean (SD)] ** & \\
Mother & $24.9(4.2)$ \\
Father & $25.2(4.0)$ \\
Adolescent & $25.5(4.1)$ \\
Satisfaction with food-related life [mean (SD)] ** & \\
Mother & $23.5(4.6)$ \\
Father & $24.2(4.1)$ \\
Adolescent & $24.4(4.7)$
\end{tabular}

SD: standard deviation.

* The high and upper-middle socioeconomic status include householders with complete secondary or incomplete technical education, complete technical education or incomplete university, complete university and postgraduate studies (master, doctorate or equivalent) and occupations like low and mid-level administrative employee, salesperson, secretary, mid-level executive, general manager, traditional professional and senior executive or general manager. The middle-middle socioeconomic status includes householders with incomplete elementary education or less, complete elementary, incomplete secondary, complete secondary or incomplete technical education, complete technical education or incomplete university, complete university and postgraduate studies (master, doctorate or equivalent) and occupations like skilled worker, junior, foreman, microentrepreneur, low and mid-level administrative employee, salesperson, secretary, mid-level executive, general manager, traditional professional and senior executive or general manager. The lower-middle socioeconomic status includes householders with incomplete elementary education or less, complete elementary, incomplete secondary, complete secondary or incomplete technical education, complete technical education or incomplete university, complete university and postgraduate studies (master, doctorate or equivalent) and occupations like occasional and informal minor work, unskilled worker, odd jobs worker, day laborer, skilled worker, junior, foreman, microentrepreneur, low and mid-level administrative employee, salesperson, secretary, mid-level executive, general manager, traditional professional. The low socioeconomic status includes householders with incomplete elementary education or less, complete elementary, incomplete secondary, complete secondary or incomplete technical education and occupations like occasional and informal minor work, unskilled worker, odd jobs worker, day laborer, skilled worker, junior, foreman, microentrepreneur. The very low socioeconomic status includes householders with incomplete elementary education or less, complete elementary and occupations in occasional and informal minor work, unskilled worker, minor tradesperson, day laborer.

** Potential score range 5-30. 
The Actor-partner Interdependence Model model of the effect of Satisfaction with Food-related Life (SWFL) on Satisfaction with Life Scale (SWLS) in dual-earner parents and their adolescent children. Temuco, Chile, 2017.

\begin{tabular}{lcc}
\hline & & SWLS \\
& Estimate & p-value \\
\hline Father (actor) & & \\
SWFL actor effect (spillover) & 0.520 & 0.000 * \\
Mother SWFL partner effect (mother crossover) & 0.028 & 0.704 \\
Children SWFL partner effect (children crossover) & 0.036 & 0.565 \\
Mother (actor) & & \\
SWFL actor effect (spillover) & 0.338 & 0.000 * \\
Father SWFL partner effect (father crossover) & 0.157 & 0.027 ** \\
Children SWFL partner effect (children crossover) & 0.033 & 0.545 \\
Children (actor) & & 0.000 * \\
SWFL actor effect (spillover) & 0.668 & 0.423 \\
Father SWFL partner effect (mother crossover) & 0.055 & 0.866 \\
Mother SWFL partner effect (children crossover) & -0.012 & \\
\hline
\end{tabular}

SWLS: scores were obtained by summing up the scores from the 5 items on the scale; SWFL: scores were obtained by summing up the scores from the 5 items on the scale.

* $\mathrm{p} \leq 0.01$;

$\star * \mathrm{p} \leq 0.05$.

\section{Discussion}

Using an APIM triadic approach, this study focused on exploring spillover and crossover associations between satisfaction with food-related life and life satisfaction in mothers, fathers and adolescent children in dual-earner families. As hypothesized, the results show a positive spillover between satisfaction with food-related life and life satisfaction in the three family members. The positive association between satisfaction with food-related life and life satisfaction are consistent with previous studies with adolescents 13,14,21,23 and adults 14,25. Although according to Cohen 43 the associations between each family member's satisfaction with food-related life and their satisfaction with life presented medium strength; notably the spillover association in children was the strongest, followed by the spillover association in fathers and finally by the spillover association in mothers. Therefore, it is possible to suggest that spillover association between satisfaction with food-related life and satisfaction with life is related to gender and age.

No bidirectional crossovers between the three family members were found, which is in line with some studies that found no crossover effects between different variables when studying dyads 31 . These results are consistent with the lack of correlations between children's and their parent's satisfaction with food-related life and satisfaction with life. However, this is an unexpected result considering the evidence indicating that eating habits 6,28 and satisfaction with food-related life 6 are related among family members. However, one possible explanation may be related to the low frequency of family meals in dual-earner families that experience conflicting work and school schedules 15,16,17,18. Therefore, considering that life satisfaction and food-related life satisfaction are related to greater family support, more frequent family meals and higher cohesion of family around eating 5,9,10,11,12,13,14, it is possible that one family member's satisfaction with food-related life may not cross over to the other members' life satisfaction when the frequency of family meals is low. Although further research is necessary to explain the lack of crossover between parents and children, another possible explanation may be related to the differences on age between parents and their children. While age is expected to increase the importance of eating habits associated with satisfaction with food-related life 44 , younger people are expected to focus on pleasant experiences and tend to have 
more hedonistic and unhealthful eating habits 45 . Moreover, although parents are still responsible for mealtimes during adolescence 18 , adolescents are more likely to choose their own foods and meals and to obtain food outside the household ${ }^{46}$. Therefore, we could also hypothesize that children's satisfaction with food-related life does not cross over to their parents' life satisfaction, if children's eating habits do not fulfill the eating habits their parents wish for them.

However, the results show a unidirectional crossover from the father's satisfaction with foodrelated life to his partner's life satisfaction, whereas the father's life satisfaction was not associated with his partners' satisfaction with food-related life. These results are consistent with studies that have reported asymmetric crossover patterns among couples 47 , where the two members of a couple may differ in terms of crossover relationship significance 48 . It should also be noted that the crossover association between the fathers' satisfaction with food-related life and the mothers' life satisfaction presented a low strength, thus suggesting that the spillover effect is more relevant than the crossover in the association between satisfaction with food-related life and life satisfaction in mothers. Although further research is required to understand the lack of a woman's partner effect on the association between her satisfaction with food-related life and her partner's life satisfaction, these results may be related to the cultural context of this study. In fact, a traditional family structure still prevails in Latin America, where men are the main householders and women are still the primarily responsible for the home-food environment and meals. Therefore, women are expected to assume more responsibilities to keep their work life from intruding into family life 30 , which includes the responsibility for food shopping, meal planning and cooking. Considering this, if the woman fulfills her partner's meals requirements, her partner will possibly report a higher level of satisfaction with his food-related life, and thereby cross over to his partner's (woman's) life satisfaction. It may be also possible that in these conditions a higher satisfaction with food-related life in a woman does not necessarily influence her partner's overall life satisfaction. Therefore, further research is required in countries or cultures with a different family structure.

The strengths of this study lie in the survey carried out with mothers-father-adolescent triads. Validated measures of well-being were used and study sample included socioeconomically diverse families. Furthermore, the triadic APIM approach makes it possible to analyze three family members simultaneously, considering their overall life satisfaction and satisfaction with food-related life. Therefore, the results contribute to the body of research regarding the crossover of positive experiences, which has received considerably less attention than those studies focusing on the crossover of negative experiences 32,34 . Moreover, this study is the first to consider that satisfaction in the food domain possibly cross over to the family members' life satisfaction. Among the study limitations is its cross-sectional design, requiring caution on causal relationships. Another limitation is related to the non-probabilistic nature of the sample and its relatively small size, which does not permit the generalization of our results. Although the sample is similar to the Chilean population in terms of the number of family members and children per family, it has a different composition in terms of families' socioeconomic status. Thus, the sample presents greater proportions of families belonging to the middle-middle and lower-middle socioeconomic status (12\%, $25 \%$, respectively), and a lower presence of families belonging to the low socioeconomic status (37\%) than the Chilean population 49. This situation may affect the results of this study, considering that higher socioeconomic status has been related to higher levels of life and food-related life satisfaction 5 , whereas it has been reported that socioeconomic status moderates the relationship between food-related life satisfaction and life satisfaction in adolescents 13 . Therefore, future studies should consider samples with a composition similar to the country's socioeconomic status. Moreover, the study examined only families with adolescent children, which limits the results from being extrapolated to families at other life cycle stages. This situation may also affect the results, considering that young children are still more influenced by their families' eating habits and parental control than adolescent children 7. In fact, as children age, they want to make their own decisions regarding what and when eat 46,50 , while it seems that controlling, or monitoring food-related parenting practices tend to decrease or may be ineffective 7 . Indeed, it is common that when children age or during adolescence, they may be home alone and many of their mealtimes are unsupervised by an adult 51 . Therefore, it is possible that the lack of correlations between children's and their parents' satisfaction with food-related life and the lack of crossover between parents and children may be related to the children's life stage. Furthermore, all data were 
self-reported; therefore, responses may have been affected by social desirability. Moreover, parents were asked neither about their type of job nor number of working hours, which may affect the frequency of family meals and the family members' quality of diet - aspects related to life and food-related life satisfaction - if parents have difficulties in combining family and work 15,16,17,18. Participants were not asked about the frequency of family meals, and the diet quality of the three family members was not assessed, which are associated with the levels of satisfaction aspects approached in this study $3,4,5,6,7,8,9,10,11,14$. Also, participants were not asked about the food-related parenting practices used at mealtimes, while family support and the level of family cohesion around eating where not evaluated, which have also been associated with different levels of life and food-related life satisfaction in adolescents and their parents $5,7,8,9,10,11,12,13,14,25,52$.

\section{Conclusions}

Using a triadic APIM approach, positive spillovers were found between satisfaction with food-related life and life satisfaction in mothers, fathers and their adolescent children in dual-earner families. Therefore, future research should also assess variables which may have spillover effects on the satisfaction with food-related in family members as well as other food-related variables that may have spillover effects on life satisfaction. In this regard, both positive (e.g., higher frequency of family meals, healthy food-related parenting practices) and negative (e.g., unhealthful eating habits, inadequate nutritional statuses) spillovers should be assessed. However, considering that the strength of the spillovers differs among family members, future studies should also evaluate possible moderating roles of age and gender. As no bidirectional crossovers between the three family members were found, further research is required to better understand the lack of a partner effect on the association between satisfaction with food-related life and life satisfaction, in particular between parents and their adolescent children. Furthermore, future studies should explore the reasons for the unidirectional crossover from a man's satisfaction with food-related life to his partner's life satisfaction, and not vice versa. Future studies should also assess spillover-crossover associations between satisfaction with foodrelated life and other life domains, such as family, work and leisure. Moreover, these research should also consider the parents' type of job, their number of working hours, frequency of family meals and family members' diet quality and other food and family-related variables (food-related parenting practices, family support, family cohesion around eating, among others), considering that they are related to life and food-related life satisfaction as well as to the levels of work-family conflict in working parents 15,16,17,18,30. Finally, new research is required to consider longitudinal designs in order to test causality.

The positive spillovers between satisfaction with food-related life and life satisfaction in dualearner parents detected in this study may be useful for both individuals and organizations. Organizational efforts should be made to promote satisfaction with food-related life in female and male employees, which in turn may enhance workers' satisfaction with life. This is relevant, considering that promoting employees' satisfaction with food-related life may not only improve their emotional well-being, but also protect them from overweight and obesity 5,6,8. Nevertheless, special efforts should be made by dual-earner parents to improve the variables related to their satisfaction with food-related life as well as that of their children, such as having healthful eating habits and increasing the frequency of family meals at home. In this sense, it is also important that dual-earner parents have enough time to face the food responsibilities regarding their families' properly feeding, including food shopping, meal planning and cooking. 


\section{Contributors}

B. Schnettler designed and wrote the first manuscript draft. E. Miranda-Zapata and Klaus G. Grunert guided the statistical analysis. G. Lobos and M. Lapo made a critical analysis of the final version of the manuscript. C. Hueche prepared the literature review. all authors reviewed and approved the final version for publication.

\section{Additional informations}

ORCID: Berta Schnettler (0000-0002-4438-3379); Edgardo Miranda-Zapata (0000-0003-33593052); Klaus G. Grunert (0000-0001-8482-184X); Germán Lobos (0000-0002-6155-4870); María Lapo (0000-0002-1509-7242); Clementina Hueche (0000-0002-3813-3584).

\section{Acknowledgments}

This study was funded by Conicyt, Fondecyt Project n. 1160005 and Fondecyt Project 1190017.

\section{References}

1. Diener E. New findings and future directions for subjective well-being research. Am Psychol 2012; 67:590-7.

2. Tian L, Wang D, Huebner ES. Development and validation of the Brief Adolescents' Subjective Well-Being in School Scale (BASWBSS). Soc Indic Res 2015; 120:615-34.

3. Kelishadi R, Qorbani M, Heshmat R, Motlagh ME, Magoul A, Mansourian M, et al. Determinants of life satisfaction in Iranian children and adolescents: the CASPIAN-IV study. Child Adolesc Ment Health 2018; 23:228-34.

4. Lobos G, Schnettler B, Grunert KG, AdasmeBerríos C. Perceived resources as a predictor of satisfaction with food-related life among Chilean elderly: an approach with generalized linear models. J Nutr Health Aging 2017; 21:1240-9.

5. Schnettler B, Miranda H, Lobos G, Orellana L, Sepúlveda J, Denegri M, Etchebarne S, Mora M, Grunert KG. Eating habits and subjective well-being: a typology of students in Chilean state universities. Appetite 2015; 89:203-14.

6. Schnettler B, Lobos G, Miranda-Zapata E, Denegri M, Ares G, Hueche C. Diet quality, satisfaction with life, family life and foodrelated life across families: a cross-sectional study with mother-father-adolescent triads. Int J Environ Res Public Health 2017; 14:1313.

7. Schnettler B, Grunert KG, Lobos G, MirandaZapata E, Denegri M, Hueche C. Maternal food-related practices, quality of diet and wellbeing: profiles of Chilean mother-adolescent dyads. J Nutr Educ Behav 2018; 50:776-87.

8. Schnettler B, Grunert KG, Lobos G, MirandaZapata E, Denegri M, Ares G, et al. A latent class analysis of family eating habits in families with adolescents. Appetite 2018; 129:37-48.

9. Utter J, Denny S, Lucassen M, Dyson B. Adolescent cooking abilities and behaviors: Associations with nutrition and emotional wellbeing. J Nutr Educ Behav 2016; 48:35-41.

10. Utter J, Denny S, Peiris-John R, Moselen E, Dyson B, Clark T. Family meals and adolescent emotional well-being: findings from a national study. J Nutr Educ Behav 2017; 49:67-72.

11. Bogea EG, Martins MLB, Carvalho WRC, Arruda SPM, Franca AKTC, Silva AAM. Padrões alimentares de crianças de 13 a 35 meses de idade e associação com características maternas. Cad Saúde Pública 2019; 35:e00072618.

12. Schnettler B, Miranda-Zapata E, Grunert KG, Lobos G, Denegri M, Hueche C, et al. Life satisfaction of university students in relation to family and food in a developing country. Front Psychol 2017; 8:1522.

13. Schnettler B, Miranda-Zapata E, Grunert KG, Lobos G, Denegri M, Hueche C. Weight fluctuation and diet concern negatively affect food-related life satisfaction in Chilean male and female adolescents. Front Psychol 2018; 9:1013. 
14. Schnettler B, Grunert KG, Lobos G, MirandaZapata E, Denegri M, Hueche C. Exploring relationships between family food behaviour and well-being in single-headed and dualheaded households with adolescent children. Curr Psychol 2018; Online First. https://link. springer.com/article/10.1007/s12144-0189974-8.

15. Agrawal T, Farrell TJ, Wethington E, Devine CM. "Doing our best to keep a routine:" How low-income mothers manage child feeding with unpredictable work and family schedules. Appetite 2018; 120:57-66.

16. Nepper MJ, Chai W. Parents' barriers and strategies to promote healthy eating among schoolage children. Appetite 2016; 103:157-64.

17. Park S, Sung E, Choi Y, Ryu S, Chang Y, Gittelsohn J. Sociocultural factors influencing eating practices among office workers in urban South Korea. J Nutr Educ Behav 2017; 49:466-74.

18. Pearson N, Griffiths P, Biddle SJ, Johnston JP, Haycraft E. Individual, behavioural and home environmental factors associated with eating behaviours in young adolescents. Appetite 2017; 112:35-43.

19. Diener E, Ryan K. Subjective well-being: a general overview. S Afr J Psychol 2009; 39:391406.

20. Baumann M, Tchicaya A, Vanderpool K, Lorentz N, Le Bihan E. Life satisfaction, cardiovascular risk factors, unhealthy behaviours and socioeconomic inequality, 5 years after coronary angiography. BMC Public Health 2015; 15:668.

21. Schnettler B, Miranda-Zapata E, Lobos G, Saracostti M, Denegri M, Lapo M, et al. The mediating role of family and food-related life satisfaction in the relationships between family support, parent work-life balance and adolescent life satisfaction in dual-earner families. Int J Environ Res Public Health 2018; 15:2549.

22. Vaqué C, González M, Casas F. Food indicators and their relationship with 10 to 12 yearolds' subjective well-being. Child Indic Res 2012; 5:735-52.

23. Vaqué-Crusellas C, González M, Casas F. Does satisfaction with food matter? Testing the personal well-being Index-School Children (PWISC) with an additional item on satisfaction with food on a sample of 10 to 12 -year-olds. Child Indic Res 2015; 8:961-73.

24. Viljoen AT, van der Spuy E, du Rand GE. Food consumption, lifestyle patterns, and body mass index of a group of white South African students. Int J Consum Stud 2018; 42:533-546.

25. Schnettler B, Miranda H, Sepúlveda J, Denegri M, Mora M, Lobos G, Grunert KG. Psychometric properties of the Satisfaction with Food-Related Life Scale: application in southern Chile. J Nutr Educ Behav 2013; 45:443-9.

26. Kenny DA, Kashy DA, Cook WL. Dyadic data analysis. New York: Guilford Press; 2006.
27. Katapodi MC, Ellis KR, Schmidt F, Nikolaidis C, Northouse LL. Predictors and interdependence of family support in a random sample of long-term young breast cancer survivors and their biological relatives. Cancer Med 2018; 7:4980-92.

28. Holsten JE, Deatrick JA, Kumanyika S, PintoMartin J, Compher CW. Children's food choice process in the home environment: a qualitative descriptive study. Appetite 2012; 58:64-73.

29. Bakker AB, Demerouti E. The spillover-crossover model. In: Grzywacz JG, Demerouti E, editors. Current issues in work and organizational psychology. New frontiers in work and family research. New York: Psychology Press; 2013; p. 55-70.

30. Matias M, Ferreira T, Vieira J, Cadima J, Leal T, Matos P. Work-family conflict, psychological availability, and child emotion regulation: Spillover and crossover in dual-earner families. Personal Relationships 2017; 24:623-39.

31. Kerr ME, Bowen M. Family evaluation. New York: W.W. Norton; 1988.

32. Steiner R, Krings F. How was your day, darling? A literature review of positive and negative crossover at the work-family interface in couples. Eur Psychol 2016; 21:296-315.

33. Demerouti E, Bakker AB, Schaufeli WB. Spillover and crossover of exhaustion and life satisfaction among dual-earner parents. J Vocat Behav 2005;67:266-89.

34. Rodríguez-Muñoz A, Sanz-Vergel AI, Demerouti E, Bakker AB. Engaged at work and happy at home: a spillover-crossover model. J Happiness Stud 2014; 15:271-83.

35. Calvo A, Tartakowsky A, Maffei T. Transformaciones en las estructuras familiares en Chile. http://www.ministeriodesarrollosocial.gob.cl/ btca/txtcompleto/mideplan/transformac.fam. chilenas.pdf (accessed on 05/Jul/2017).

36. Diener E, Emmons R, Larsen R, Griffin S. The satisfaction with life scale. J Pers Assess 1985; 49:71-5.

37. Schnettler B, Miranda H, Sepúlveda J, Denegri M. Satisfacción con la alimentación y la vida, un estudio exploratorio en estudiantes de la Universidad de La Frontera, Temuco-Chile. Psicol Soc 2011; 23:426-35.

38. Grunert KG, Dean M, Raats MM, Nielsen NA, Lumbers M. A measure of satisfaction with food-related life. Appetite 2007; 49:486-93.

39. Hambleton RK. Issues, designs, and technical guidelines for adapting test into multiple languages and cultures. In: Hambleton RK, Merenda PF, Spielberger CD, editors. Adapting educational and psychological tests for crosscultural assessment. Mahwah: Lawrence Erlbaum; 2005; p. 3-38

40. Adimark. El nivel socio económico Esomar. Manual de aplicación. https://www.microweb. $\mathrm{cl} / \mathrm{idm} /$ documentos/ESOMAR.pdf (accessed on 30/Apr/2016). 
41. Hu LT, Bentler PM. Cutoff criteria for fit in dexes in covariance structure analysis: conventional criteria versus new alternatives. Struct Equ Modeling 1999; 6:1-55.

42. Marsh HW, Hau KT, Grayson D. Goodness of fit evaluation in structural equation modeling. In: Maydeu-Olivares A, McArdle J, editors. Contemporary psychometrics. A Festschrift for Roderick P. McDonald. Mahwah: Lawrence Erlbaum Associates; 2005. p. 275-340.

43. Cohen J. Statistical power analysis for the behavioral sciences. Mahwah: Lawrence Erlbaum Associates; 1988.

44. Schnettler B, Miranda H, Miranda-Zapata E, Salinas-Oñate N, Grunert KG, Lobos G, et al. Longitudinal multigroup invariance analysis of the satisfaction with food-related life scale in university students. Appetite 2017; 113:91-9.

45. Kahma N, Niva M, Helakorpi S, Jallinoja P. Everyday distinction and omnivorous orientation: an analysis of food choice, attitudinal dispositions and social background. Appetite 2016; 96:443-53.

46. Fink SK, Racine EF, Mueffelmann RE, Dean MN, Herman-Smith R. Family meals and diet quality among children and adolescents in North Carolina. J Nutr Educ Behav 2014; 46:418-22.

47. Westman M, Vinokur A, Hamilton L, Roziner I. Crossover of marital dissatisfaction during downsizing: a study of Russian army officers and their spouses. J Appl Psychol 2004; 89:759-79.
48. Liu H, Cheung FM. Testing crossover effects in an actor-partner interdependence model among Chinese dual-earner couples. Int J Psychol 2015; 50:106-11.

49. Asociación Investigadores de Mercado. Nueva metodología de segmentación y clasificación socioeconómica. https://www.pauta.cl/ pauta/site/docs/20180622/20180622170601/ aim_nuevo_gse_2018.pdf (accessed on 02/ Aug/2019).

50. Marshall D. Feeding in context: feeding children inside and outside the home. Critical perspectives. In: Harman V, Cappellini B. Fairclough C, editors. Feeding children Inside and outside the home: critical perspectives. London: Routledge; 2018. p. 134-51.

51. Reicks M, Banna J, Cluskey M, Gunther C, Hongu N, Richards R, et al. Influence of parenting practices on eating behaviors of early adolescents during independent eating occasions: implications for obesity prevention. $\mathrm{Nu}-$ trients. 2015;7:8783-801.

52. Schnettler B, Rojas J, Grunert KG, Lobos G, Miranda-Zapata E, Lapo M, et al. Family and food variables that influence life satisfaction of mother-father-adolescent triads in a South American country. Curt Psychol 2019; Online First. https://link.springer.com/ar ticle/10.1007/s12144-019-00328-4. 


\section{Resumen}

Este estudio exploró las asociaciones spillover $y$ crossover entre la satisfacción con la alimentación y la vida en madres, padres y niños adolescentes, en familias con dos fuentes de ingresos. El diseño del estudio es transversal con madres, padres y niños, realizado en Temuco, Chile. Los participantes fueron 303 parejas con ingresos (cada uno de los miembros) y sus hijos adolescentes (promedio de edad 13,3 años, 51,5\% mujeres). Se utilizó un modelo de interdependencia actorcompañero (Actor-partner Interdependence Model - APIM por sus siglas en inglés) y modelos de ecuación estructural para investigar las asociaciones spillover (efecto actor) y crossover (efecto compañero) entre los miembros de las familias. En los resultados, la satisfacción con la alimentación de los padres estuvo positivamente asociada con su propia satisfacción vital ( $p \leq 0,01)$, al igual con la satisfacción vital de su pareja (la madre, $p \leq 0,05$ ), pero no con la satisfacción con la vida de su hijo adolescente $(p>0,1)$. Madres e hijos mostraron asociaciones spillover positivas entre sus propios niveles de satisfacción con la alimentación y la satisfacción con la vida $(p \leq 0,01)$. No hubo efectos crossovers entre madres e hijos $(p>0,1)$. Los resultados de este estudio destacan la asociación positiva entre la satisfacción con la alimentación y la satisfacción vital entre miembros de familias con dos ingresos e hijos adolescentes. Se deberían realizar esfuerzos especiales en las parejas con ingresos por ambas partes para mejorar las variables relacionadas con su satisfacción con la alimentación, así como también con de su hijos.

Satisfacción Personal; Adolescente;

Alimentación

\section{Resumo}

Este estudo explorou as associações de spillover e crossover entre a satisfação com a vida relacionada à alimentação e a satisfação com a vida em geral em mães, pais e filhos adolescentes em famílias com duas fontes de renda. O delineamento é de um estudo transversal em mães, pais e filhos em Temuco, Chile. Os participantes eram 303 casais com duas fontes de renda e seus filhos adolescentes (média de idade de 13,3 anos, sendo 51,5\% do sexo feminino). Foram usados o Actor-partner Interdependence Model (APIM) e modelagem de equações estruturais para explorar as associações spillover (efeito de ator) e crossover (efeito de parceiro) entre membros da família. Nos resultados, a satisfação do pai com a vida relacionada à alimentação mostrou associação positiva com a satisfação em relação à própria vida $(p \leq 0,01)$, assim como, com a satisfação da parceira com a vida (a mãe, $p \leq 0,05)$, mas não com a satisfação do filho adolescente com a vida $(p>0,1)$. As mães $e$ filhos mostraram desdobramentos positivos entre seus próprios níveis de satisfação com a vida relacionada à alimentação e a satisfação com a vida $(p \leq 0,01)$. Não foram encontrados efeitos crossovers entre as mães e os filhos $(p>0,1)$. Os achados do estudo sublinham a associação positiva entre a satisfação com a vida relacionada à alimentação e a satisfação com a vida em geral entre membros de famílias com duas fontes de renda e filhos adolescentes. Os casais com duas fontes de renda devem se esforçar para melhorar as variáveis relacionadas à sua própria satisfação e de seus filhos em relação à alimentação.

Satisfação Pessoal; Adolescente; Alimentação
Submitted on 11/May/2019

Final version resubmitted on 02/Sep/2019 Approved on 16/Sep/2019 